\title{
B2
}

\author{
doi: 10.14232/fgykf.2018.b2
}

\section{Furokumarinok, mint az édeskömény potenciálisan toxikus összetevői}

\author{
Kerekes Diána ${ }^{1}$ Csorba Attila, ${ }^{1}$ Gosztola Beáta, ${ }^{2}$ Zámboriné Németh Éva, ${ }^{2}$ \\ Csupor Dezsö ${ }^{1}$ \\ ${ }^{1}$ Szegedi Tudományegyetem, Farmakognóziai Intézet, 6720 Szeged, Eötvös utca 6.
${ }^{2}$ Szent István Egyetem, Gyógy- és Aromanövények Tanszék, 1118 Budapest, Villány út 29-43.
}

$\mathrm{Az}$ édeskömény (Foeniculum vulgare Mill.) gyakran alkalmazott gyógy- és élelmiszernövény, amelyet már a tradicionális gyógyászatban is alkalmaztak, de mind a mai napig használják köptető, görcsoldó, tejelválasztást fokozó készítményekben. Hazánkban is több gyógyszerben és gyógytermékekben is forgalomban van.

Korábbi vizsgálatok kimutatták, hogy az édeskömény tartalmaz lineáris furokumarinokat - bergaptént, imperatorint, és pszoralént - ám mennyiségi adatok nem állnak rendelkezésre. Ezekről a vegyületekről bizonyították, hogy számos toxikus - például karcinogén, genotoxikus, mutagén - hatásokkal bírnak. Ezek közül is a legjellemzőbb a fototoxicitás, amelyeket humán vizsgálatok is alátámasztottak. A potenciálisan ártalmas hatások miatt az Európai Gyógyszerügynökség (EMA) bizonyos furokumarintartalmú növények esetén korlátozza az alkalmazást, különösen terhességben és gyermekkorban.

Célul tűztük ki, hogy igazoljuk a furokumarinok jelenlétét édesköménymintákban, és meghatározzuk ezek mennyiségét a termésben. További célunk volt, hogy szakirodalmi adatok és saját méréseink alapján pedig alátámasszuk vagy megcáfoljuk, hogy a növényben található mennyiség valóban ad-e okot a toxikus hatásoktól való félelemre. Munkánk során 33 különböző édeskömény mintát vizsgáltunk. A mérési módszerünkkel az imperatorint nem tudtuk kimutatni, ám 7 minta kivételével a bergaptént és pszoralént HPLC-MS segítségével detektálni tudtuk. Ha a mennyiségeket a terápiás dózis napi maximális adagjára vonatkoztatjuk (7,5 g), akkor a 33 mintában az összfurokumarin-tartalom 0,01-1,22 $\mu \mathrm{g}$ között volt. Ha ezt az értéket az Európai Gyógyszerügynökség legszigorúbb ajánlásához viszonyítjuk - azaz 1,5 $\mu \mathrm{g}$ furokumarinnal való tartós kezelés nem okoz toxikus hatásokat -, akkor az édeskömény furokumarin-tartalma alapján nem tekinthető potenciálisan toxikus növénynek.

Témavezető: Dr. Csupor Dezső 